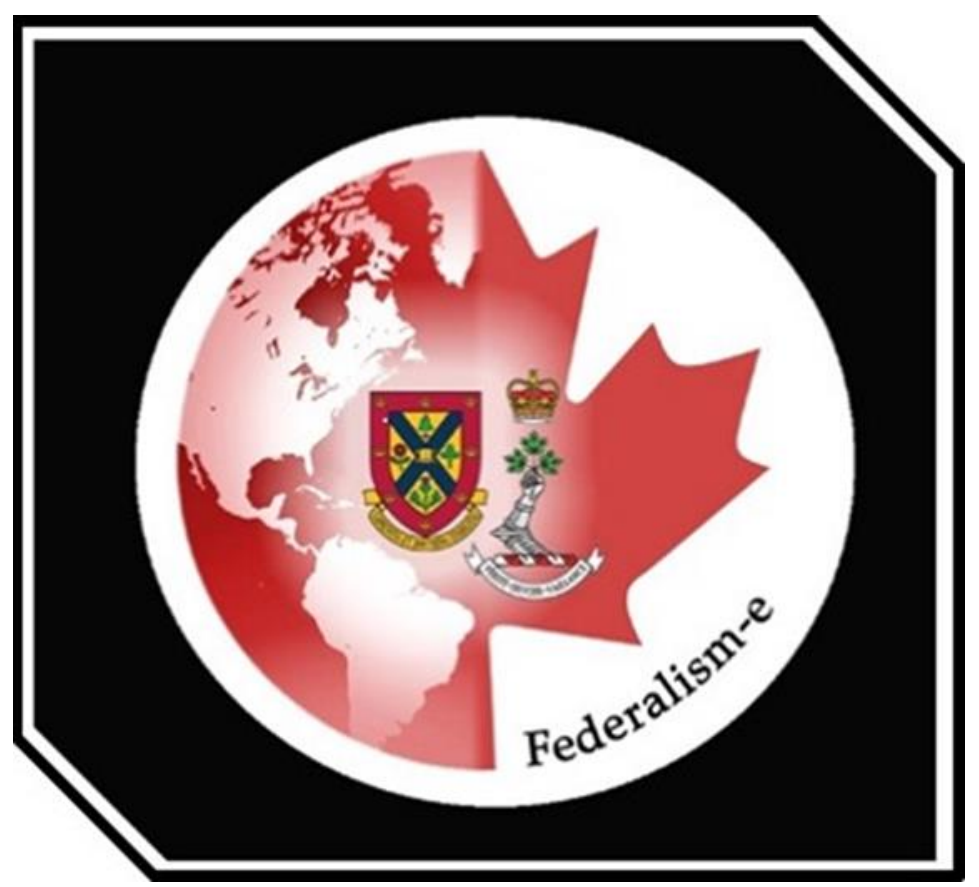

\title{
Federalism-E
}

\section{The Evolution of Canadian Federalism}

By: Isabella Rose Fusco

University of Toronto

Federalism-E is founded by the Royal Military College of Canada and the Institute of Intergovernmental Relations at Queen's University 
Federalism- $E$ is an online, undergraduate student-run journal focusing on the theory of federalism. Federalism-E publishes academic articles and essays focusing on federalism, multi-level governance, and intergovernmental relations. Publishing in both English and French, the journal has a mandate to provide a forum encouraging research and scholarly debate with respect to a wide variety of issues concerning federalism, both within Canada and abroad.

\section{Editors-in-Chief}

Officer Cadet Miles Smith, Royal Military College of Canada

Officer Cadet Alexandre Veilleux, Royal Military College of Canada

\section{Associate Editors:}

Officer Cadet Jack Wery, Royal Military College of Canada

Officer Cadet Jack Murphy, Royal Military College of Canada

Officer Cadet Damian McCracken, Royal Military College of Canada

Rylee Rose Kloek, University of Ottawa

Joyce Le-Yi Yang, University of Toronto

Mduduzi Mhlanga, University of Toronto

Srijan Sahu, University of Toronto

Jenna Mohammed, University of Toronto Mississauga

Ali Bachir Taha, University of Toronto

Charmaine Lee, University of British Columbia

Faculty Advisor:

Dr. Christian Leuprecht, Royal Military College of Canada, Institute of Intergovernmental

Relations at Queen's University

Contact Information:

Address: Royal Military College of Canada

13 General Crerar Crescent

Kingston

ON, K7K 7B4

ISSN: 2562-3435

Email: federalismeditors@gmail.com

Website: https://ojs.library.queensu.ca/index.php/fede

Federalism-E is founded by the Royal Military College of Canada and the Institute of Intergovernmental Relations at Queen's University 
Federalism is the division of power exercised in Canada, featured in various parts of Canadian society. Peter Hogg defines Federalism as, "every individual in the state is subject to the laws of two authorities, the central authorities and the regional authorities" (Hogg 1985, 80). This was first introduced as official law under the Constitution Act of 1867. Prior to, the colony that became Canada had a sense of pre-federalism, where colonies had jurisdiction over their territories whilst still operating under Britain, which occurred between Britain, 'Canada' and the provinces, which than lead to the development of Federalism. The British North America Act (Constitution Act 1867) was then created, which institutionalized Federalism, beginning with the provincial government being subordinate to the Federal government. Moving forward from the Constitution Act, the Judicial Committee of The Privy Council amended parts of the Constitution in favour of the provinces (Hogg 1985, 87), setting in motion the path to equality between the federal and provincial governments. In 1982, the Charter of Rights and Freedoms was created, which gave the provinces new kinds of powers such as the Amending Formula which requires two thirds of the provinces and fifty percent of the population in order for the Canadian constitution to change (Constitution Act 1982, Sec. 38). Leading to a common way where federalism is handled in current society, the intergovernmental negotiations, where both central and regional governments operate as equals.

In this essay, I will examine how Federalism in Canada evolved from provincial subordination to the Federal level, to equality between the divisions. This change developed throughout the division of powers within the Constitution Act of 1867, the judicial interpretations of the Judicial Committee of the Privy Council, the Constitution Act of 1982 and intergovernmental negotiations.

To begin, Federalism was entrenched in Canadian society not only with the British North America Act, but prior to the creation of the Constitution as well. When Britain colonized a certain territory, Hogg explains, "the rule of common law was that the law of the conquered people continued in force in the Colony, except in the matters involving the relationship between the conquered people and the new British sovereign" (Hogg 1985, 26). Hogg demonstrates a sense of pre-federalism, in which colonies had a say over their territories, whilst also having to operate under the sovereign government. This sense of power that was allotted to the colonies also existed in the provinces, a power the provinces were not willing to give up, which in turn created the Constitution Act of 1867 in which the division of powers was written down under Sections 91 and 92 (Constitution Act 1867, Sec. 91-92).

The Constitution Act of 1867 outlined the division of powers between the federal and provincial governments. In doing so, it also created ways in which the federal government could regulate the provincial regions. Section 90 of the Constitution Act outlined that the "federal government was given the power to disallow (i.e. invalidate) provincial statues" (Hogg 1985, 87). Throughout the power to disallow Hogg acknowledges that the sovereign federal government could remove and control provincial divisions, providing the federal government with large control over affairs. This was a power which the leading figure in Canada at the time, John A. Macdonald, aspired to obtain so that he could enact, "his vision of Canada - a vision that privileged imperial governments and regarded federalism with suspicion" (LaSelva 1996, 42). This vision clearly lingered within the Constitution Act in more ways than one. Another way in which the central powers were superior to the regional ones is in Section 91 of the Constitution 
Act of 1867, wherein lies what Gardner identifies as the POGG power, "the national government is granted the power 'to make Laws for the Peace, Order, and good Government of Canada' (the so-called POGG power)" (Gardner 2017, 10). Gardner addresses a key point in federal sovereignty, in which the central government, in the broadest sense, could control ways that the provincial government administered its powers as well as creating their own laws under the jurisdiction of provinces. Although the federal government was given significant power at first, it was slowly corrected by judicial interpretation and constitutional amendments.

The Judicial Committee of the Privy Council used their interpretations as a committee to amend certain parts of the constitution (Hogg 1985, 88). Throughout their interpretations, they lead the charge in providing the provinces with power equal to the federal government. The council was particularly critical of Section 91, believing that, "the federal POGG power was held inadequate to sustain federal regulation of economically significant industries of nationwide reach, relegating their regulation to the provinces, an extremely important power under contemporary economic condition" (Gardner 2017, 11). The Privy Council found this power to be unfair, resulting in the council allocating the power back to the provinces. Hogg referred to the Privy Council as, "they believed strongly in provincial rights, and they established precedents which elevated the provinces to coordinate status with the Dominion" (Hogg 1985, 89). In doing so, the judicial interpretations and amendments changed federalism. The advocation for provincial rights drove federalism in a different direction - direction which Simeon noted had "powerful effects in the evolution of the federal system" (Simeon 2001, 148). The Privy Council was abolished to amend in 1949 (Hogg 1985, 88), leading to the creation of the Charter of Rights and Freedoms where there was further allocation of equality between the federal and provincial powers.

The Charter of Rights and Freedoms became a part of the Canadian Constitution in 1982. The Charter was the next step forward in furthering the equalization of power between the provincial and federal governments. Simeon identified constitutional change as, "the most definitive and long-lasting way to change a federation is to change the constitution - whether by altering the division of powers, changing fiscal relations, creating or dis-banding intergovernmental machinery, or, more broadly, by making more fundamental changes to the broader political structure" (Simeon 2001, 147). Within the division of powers, the provinces were allocated some power in constitutional change. As the Charter established the amending formula, which under Section 38 subsections B, it outlined that, "the general amending rule requires that any amendment proposed by Parliament be ratified by 'at least two-thirds of the provinces that have, in the aggregate, ... at least fifty percent of the population of all the provinces" (Gardner 2017, 12). Not only did this provide provinces with a voice through the amendment, but also the federal government under Subsection A, which required agreement in both the Senate and House of Commons for a Constitutional change to be made (Constitution Act 1982, Sec. 38(A)). Thus, the division of powers was made equal between the two levels of government by providing both levels with an equal operation of control, where no abuse of power from either level of government could operate.

In opposition to the Charter providing a further division of powers in which the federal and provincial become equal, an argument can be made that the leading figure in the history of the constitution, Pierre Trudeau, had priorities other than progressing the development of 
Federalism. Samuel V. LaSelva examines Trudeau's priorities as, "not only a federalist; he was also a multiculturalist ... In fact, Trudeau insisted that his most basic concern was not federalism but justice" (LaSelva 1996, 67). In LaSelva's argument, he proposes that Trudeau was more concerned with giving out individual rights to the people than furthering the progression of federalism. Although Sections 2, 7-15 do outline vital individual rights and freedoms (Constitution Act 1982) for individual Canadian citizens, there are also sections that feature further power for the federal and provincial governments. An example of this would be the Notwithstanding Clause, under Section 33, which states that the "Parliament or the legislature of a province may expressly declare in an Act of Parliament or of the legislature, as the case may be, that the Act or a provision thereof shall operate notwithstanding a provision included in section 2 or sections 7 to 15 of this Charter" (Constitution Act 1982, Sec. 33). Thus, the constitution outlines how the Notwithstanding clause gives both the federal and provincial governments equal chance to limit these individual freedoms. In doing so, actually furthers the evolution of the equality of powers within the Canadian federal system, as both levels of government have equal opportunity to use the clause when they see fit. Although the constitution progressed the equality of powers within federalism, the intergovernmental negotiations place the federal and provincial governments on a leveled field, in which discussions and decisions are made by both levels of government.

The intergovernmental negotiations between the federal and provincial government provide a way for the two divided powers to negotiate outside of courts. In negotiations, both governments operate on an even level, in which no one government has a distinct power over the other. In prior times, governments would have to settle issues on federal and provincial relations in courts, but then the interaction between the two governments shifted to, "agreements among two, or even three, orders of government, or they may be "compacts" among states or provinces" (Simeon 2001, 148). Simeon addresses how governments operate together, among all levels of orders of government throughout various forms. The various ways in which federalism operates through negotiations and the communications of governments are: "departments, central agencies, secretariats, and divisions or branches within departments which oversee intergovernmental affairs. This also includes units at the sectoral and departmental level, committees, meetings and conference systems, and intergovernmental partnerships" (Johns, O'Reilly \& Inwood 2007, 22). Throughout multiple forms of communication and negotiations, federalism functions between the two levels of government, organizing ways in which their division of powers can best operate. As governments do so, federalism will operate in its best form. Therefore, one can conclude that intergovernmental negotiations is the highest form in which the two levels of government under federalism co-exist and function as equals, within systems and committees dedicated to the relationship between governments.

This essay distinguishes how federalism evolved from a system with a dominant federal government to one which had an equal division of powers between the federal and provincial governments. The means of progressing the equal division of powers changed from the entrenched Constitution Act of 1867, to the amendments and judicial interpretations made by the Judicial Privy Council in which they favoured the independence of the provinces (Hogg 1985, 89). In doing so, the Privy Council set up the path that lead the Charter to includ both governments under the amending formula which gave the provinces a voice on the Constitution, and similarly to the federal government (Gardner 2017, 12). All of these factors lead to the 
intergovernmental negotiations where in practice, the federal and provincial governments operated as equal bodies. Federalism is encompassed in every single part of Canadian life, from our hospitals and schools to our laws and taxes. Further changes to the division of powers are not needed, as in current Canadian society the provinces act as independent bodies, of course always within the boundaries of the federal government, but nevertheless as self-determining societies. The federal government will always carry a sense of sovereignty, for example, through the power to Disallow (Constitution Act 1867), but the way federalism has evolved has given provinces a chance to exist in a society where both levels of governments have an equal division of power. 


\section{Bibliography}

Constitution Act, British North America Act. 1867.

Constitution Act, The Charter of Rights and Freedoms. 1982.

Gardner, James A. "Canadian Federalism in Design and Practice: The Mechanics of a Permanently Provisional Constitution." Perspectives on Federalism 9, no. 3 (2017): E-1.

Hogg, Peter W. Constitutional law of Canada. Carswell Co., 1985.

Johns, Carolyn M., Patricia L. O'Reilly, and Gregory J. Inwood. "Formal and informal dimensions of intergovernmental administrative relations in Canada." Canadian Public Administration 50, no. 1 (2007): 21-41.

LaSelva, Samuel V. Moral Foundations of Canadian Federalism: Paradoxes, Achievements, and Tragedies of Nationhood. McGill-Queen's Press-MQUP, 1996.

Simeon, Richard. "Adaptability and change in federations." International Social Science Journal 53, no. 167 (2001): 145-152. 